\title{
Respiratory System Findings Test
}

National Cancer Institute

\section{Source}

National Cancer Institute. Respiratory System Findings Test. NCI Thesaurus. Code C124025.

A character or string that represents the long name of the respiratory system findings assessment. 